CZASOPISMO INŻYNIERII LA¿DOWEJ, ŚRODOWISKA I ARCHITEKTURY JOURNAL OF CIVIL ENGINEERING, ENVIRONMENT AND ARCHITECTURE JCEEA, t. XXXIV, z. 64 (4/I/17), październik-grudzień 2017, s. 7-28, DOI:10.7862/rb.2017.188

\author{
Barbara TUROŃ ${ }^{1}$ \\ Dominika ZIAJA ${ }^{2}$ \\ Bartosz MILLER ${ }^{3}$
}

\title{
REJESTRACJA I ANALIZA PÓL PRZEMIESZCZEŃ I ODKSZTALCEŃ ZA POMOCĄ SYSTEMU CYFROWEJ KORELACJI OBRAZU 3D
}

\begin{abstract}
W ostatnich latach jako alternatywę dla tradycyjnych metod pomiarowych przemieszczeń i odkształceń zaczęto intensywnie rozwijać metody bezkontaktowego pomiaru opierające się na systemach optyczno-elektronicznych. Jednym z takich bezkontaktowych systemów pomiarowych jest system cyfrowej korelacji obrazu (ang. Digital Image Correlation, DIC), umożliwiający rejestrację i analizę pól przemieszczeń i odkształceń na powierzchni badanego obiektu w przestrzeni trójwymiarowej. W artykule przedstawiono system 3D DIC na przykładzie systemu Q-450 firmy Dantec Dynamics oraz jego zastosowanie w badaniach połączeń elementów konstrukcji stalowych; omówiono zasadę jego działania i etapy badań. Ponadto w pracy opisano zalety i ograniczenia systemu oraz zakres jego zastosowań. Narzędzia analizy pól przemieszczeń i odkształceń dostępne w programie Istra 4D, stanowiącym część systemu Q-450, pozwalają na szczegółowe określenie deformacji próbki i zjawisk zachodzących w czasie jej obciążania oraz stwarzają możliwość różnorodnej wizualizacji wyników badań. Informacje zawarte w artykule mogą być przydatne dla przyszłych użytkowników systemu i przyczynić się do szerszego stosowania metod bezkontaktowych w pomiarach przemieszczeń i odkształcen.
\end{abstract}

Słowa kluczowe: cyfrowa korelacja obrazu (DIC), metody wizyjne, pomiar bezkontaktowy, pomiary przemieszczeń i odkształceń

\section{Wprowadzenie}

Techniki pomiarowe przemieszczeń i odkształceń opierają się głównie na kontaktowych systemach pomiarowych. Stosowanie tych systemów często wiąże się z występowaniem problemów podczas zamocowania czujników po-

${ }^{1}$ Autor do korespondencji / corresponding author: Barbara Turoń, Politechnika Rzeszowska, Katedra Mechaniki Konstrukcji, ul. Poznańska 2, 35-959 Rzeszów; tel. 178651622; bturon@prz.edu.pl

${ }^{2}$ Dominika Ziaja, Politechnika Rzeszowska, Katedra Mechaniki Konstrukcji, ul. Poznańska 2, 35-959 Rzeszów; tel. 178651618; dziaja@prz.edu.pl

${ }^{3}$ Bartosz Miller, Politechnika Rzeszowska, Katedra Mechaniki Konstrukcji, ul. Poznańska 2, 35-959 Rzeszów; tel. 178651623; bartosz.miller@prz.edu.pl 
miarowych na powierzchni próbki, a wyniki badań uzyskuje się jedynie w wybranych punktach próbki, w których czujniki te zostały zamocowane. Przeprowadzone $\mathrm{w}$ ten sposób pomiary nie dają pełnej informacji o deformacji badanej próbki. Często czujniki kontaktowe można stosować jednorazowo, a podczas badań, np. rozciągania, szybciej ulegają zniszczeniu niż próbka. Ograniczenia, jakie wynikają z tego faktu, nie pozwalają na dokładną analizę mierzonych wielkości. Zastosowanie metod kontaktowych w badaniach laboratoryjnych jest czasochłonne i kosztowne. W związku z tym poszukuje się nowych technik pomiarowych, które zapewnią lepsze możliwości pomiaru przemieszczeń i odkształceń badanych obiektów.

W ostatnich latach jako alternatywę dla tradycyjnych metod pomiarowych przemieszczeń i odkształceń zaczęto intensywnie rozwijać metody bezkontaktowego pomiaru, które opierają się na systemach optyczno-elektronicznych. Metody te ogólnie zwane są metodami wizyjnymi. Tematyka metod wizyjnych podejmowana była w licznych pracach naukowych (np. [1, 2, 3]). Jednym z bezkontaktowych systemów pomiarowych jest system cyfrowej korelacji obrazu, $z$ angielskiego Digital Image Correlation (DIC), umożliwiający rejestrację i analizę pól przemieszczeń i odkształceń na powierzchni badanego obiektu w przestrzeni dwuwymiarowej lub trójwymiarowej w oparciu o korelację obrazów cyfrowych badanego obiektu zarejestrowanych podczas jego przemieszczania się i/lub odkształcania się. Stosowanie metody korelacji obrazu do pomiaru przemieszczeń sięga lat $80 \mathrm{XX}$ wieku $[4,5,6]$, jednak dopiero w ostatnich latach intensywne badania pozwoliły na znaczący rozwój i udoskonalenie tej metody, między innymi poprzez wykorzystanie w pomiarach kamer cyfrowych wysokiej rozdzielczości. W polskiej literaturze można znaleźć wiele ciekawych prac związanych z cyfrową korelacją obrazów i jej zastosowaniem w różnych obszarach nauki, jak na przykład prace autorów: Uhl T., Kohut P., Holak K. [7] czy Szymczak T., Kowalewski Z. L., Brodecki A. [8]. Bezkontaktowe metody pomiarowe stanowią alternatywę dla metod badawczych z wykorzystaniem kontaktowych czujników pomiarowych, nie eliminują one wszystkich ograniczeń pomiarów, ale pozwalają na wykonanie pomiarów w przypadkach, w których stosowanie tradycyjnych metod jest utrudnione lub nawet niemożliwe. Metody te stwarzają szersze możliwości badawcze, jak na przykład umożliwiają analizę przemieszczeń i odkształceń na całej badanej powierzchni obiektów, nie ograniczając badań do pomiarów punktowych.

W artykule przedstawiono system cyfrowej korelacji obrazu 3D do pomiaru przemieszczeń i odkształceń na przykładzie systemu Q-450 firmy Dantec Dynamics oraz jego zastosowanie $\mathrm{w}$ badaniach połączeń elementów konstrukcji stalowych; omówiono zasadę jego działania i etapy pomiaru, zwracając uwagę na problemy, z jakimi może spotkać się użytkownik systemu. Ponadto w pracy przedstawiono możliwości zastosowania systemu DIC oraz jego zalety i ograniczenia. 


\section{System cyfrowej korelacji obrazu do rejestracji i analizy pól przemieszczeń i odkształceń}

Pomiar przemieszczeń i odkształceń metodą cyfrowej korelacji obrazu może być wykonywany przy zastosowaniu układu składającego się z jednej, dwóch lub większej liczby kamer. Zastosowanie jednej kamery pozwala określić przemieszczenia i odkształcenia badanej próbki tylko w płaszczyźnie równoległej do płaszczyzny obrazu kamery (kamera powinna być ustawiona w kierunku prostopadłym do badanej powierzchni próbki), jest to tzw. dwuwymiarowa cyfrowa korelacja obrazu 2D-DIC (Rys. 1a). Korzystanie z co najmniej dwóch kamer rejestrujących obraz badanego obiektu z różnych kierunków umożliwia przeprowadzenie pomiaru przemieszczeń i odkształceń w przestrzeni trójwymiarowej, jest to tzw. przestrzenna cyfrowa korelacja obrazu 3D-DIC (Rys. 1b).

a)

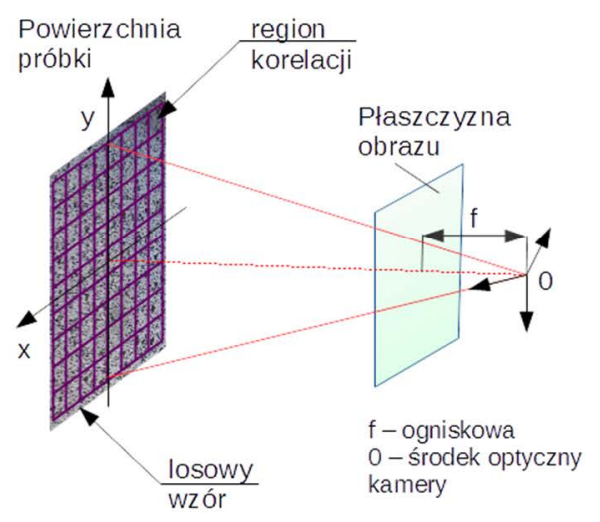

b)

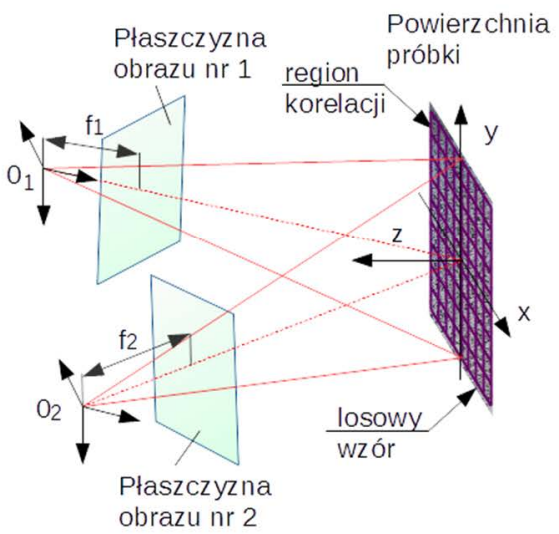

Rys. 1. Cyfrowa korelacja obrazu - 2D-DIC (a) oraz 3D-DIC (b), na podstawie [9]

Fig. 1. Digital image correlation - 2D-DIC (a) and 3D-DIC (b), based on [9]

Aktualnie opracowywane są rozbudowane systemy cyfrowej korelacji obrazu składające się z trzech, czterech, sześciu, a nawet ośmiu kamer, przeznaczone do obserwacji obiektów przestrzennych z kilku kierunków jednocześnie np. do badań obiektów cylindrycznych czy obiektów o skomplikowanym konturze przestrzennym $[9,10,11]$.

Przykładem systemu cyfrowej korelacji obrazu do pomiarów 3D jest system Q-450 firmy Dantec Dynamics. Podstawowymi elementami systemu są dwie szybkie kamery z możliwością nagrywania obrazów z częstotliwością do $130 \mathrm{kHz}$ (maksymalna prędkość kamery przy pełnej rozdzielczości obrazu wynoszącej 2560x1600 pikseli wynosi 800 klatek na sekundę). Pozostałe elementy systemu to przenośny komputer $z$ oprogramowaniem Istra 4D, urządzenie wyzwalająco-sterujące Timing Hub synchronizujące układ pomiarowy oraz tablice kalibracyjne. Schemat układu pomiarowego przedstawiono na Rys. 2 [12, 13]. 


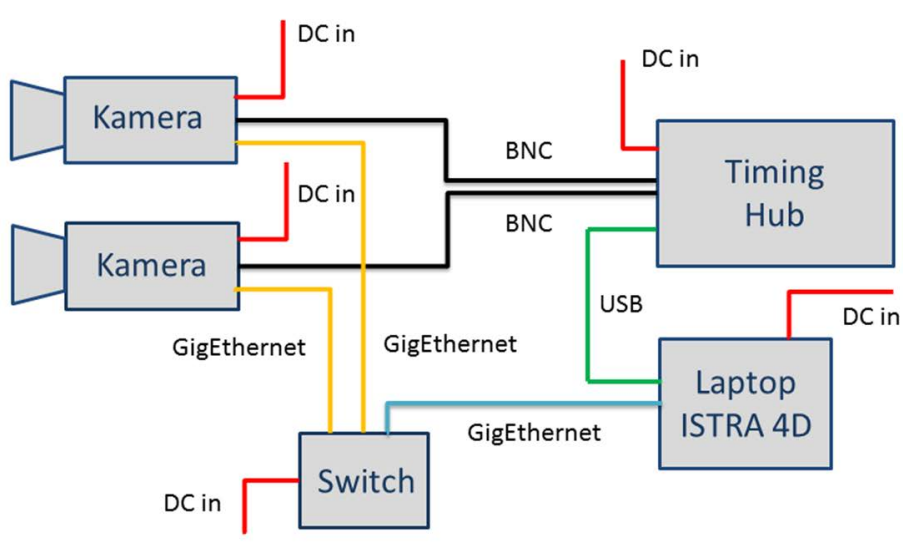

Rys. 2. Schemat układu pomiarowego Q-450

Fig. 2. Measuring system scheme Q-450

Pomiar przemieszczeń i odkształceń z zastosowaniem systemu cyfrowej korelacji obrazu Q-450 można podzielić na kilka etapów. Badanie rozpoczyna się od przygotowania powierzchni próbki oraz ustawienia stanowiska pomiarowego i kalibracji systemu, następnie wykonuje się pomiar właściwy czyli rejestrację obrazów badanego obiektu podczas jego przemieszczania się i/lub odkształcania się, kolejne etapy badania to analiza obrazów w programie Istra 4D czyli proces tzw. ewaluacji oraz wizualizacja wyników pomiaru [12].

Pomiar metodą DIC polega na wykonaniu zdjęcia badanego obiektu przed jego obciążeniem oraz zarejestrowaniu serii zdjęć po jego obciążeniu, następnie obrazy te są zapisywane i analizowane przez specjalistyczne oprogramowanie. Jeden $z$ obrazów wybierany jest jako referencyjny tj. obraz obiektu niezdeformowanego, na który nakładana jest wirtualna, regularna siatka punktów. Każdy punkt siatki wyznacza środek kwadratowego regionu obrazu zwanego regionem korelacji (Rys. 3) [11, 12]. Każdemu regionowi przyporządkowane są współrzędne jego położenia $\mathrm{w}$ określonym układzie współrzędnych (może być to układ związany z kamerą, określony podczas kalibracji systemu na podstawie pierwszego zarejestrowanego zdjęcia tablicy kalibracyjnej lub układ zadany przez użytkownika systemu). Dzięki losowemu wzorowi punktów naniesionemu przed badaniem na powierzchnię badanego obiektu możliwe jest rejestrowane i analizowanie zmiany kształtu i położenia poszczególnych regionów w trakcie obciążania obiektu, a na ich podstawie określenie przemieszczeń. Oprogramowanie systemu DIC odnajduje pozycję każdego regionu korelacji z obrazu referencyjnego na wszystkich pozostałych zarejestrowanych obrazach, a następnie oblicza przemieszczenia. System DIC Q-450 realizuje obliczenia za pomocą algorytmu korelacji w oparciu o pseudo-afiniczną transformację współrzędnych regionów korelacji wyznaczonych na obrazie referencyjnym badanego obiektu, z uwzględnieniem parametrów transformacji: translacji, rozciągnięcia, ścinania 
i dystorsji [14]. Dane wyjściowe uzyskane z pomiarów stanowi zbiór map przemieszczeń, na podstawie których wyznaczane są mapy odkształceń $[10,11,12]$.

a)

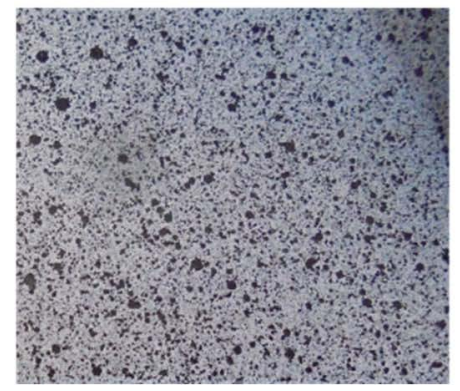

b)

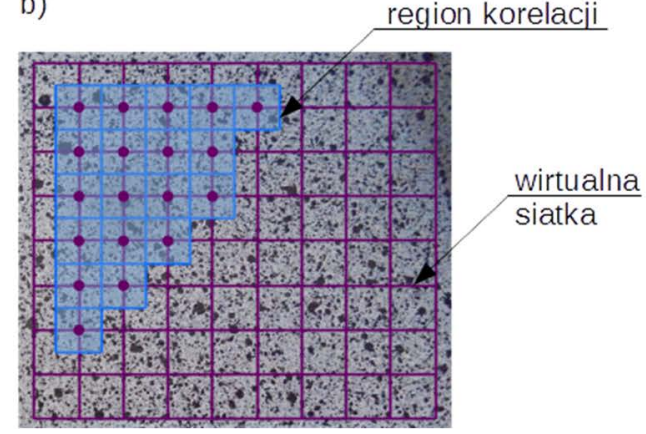

Rys. 3. Powierzchnia próbki - losowy wzór (a) oraz wirtualna siatka punktów i regionów korelacji (b), na podstawie [11]

Fig. 3. Sample surface - random pattern (a) and points of the virtual grid and facets grid (b) [11]

\section{Zalety, ograniczenia i możliwości zastosowania systemu cyfrowej korelacji obrazu 3D}

System cyfrowej korelacji obrazu 3D w stosunku do innych metod badawczych daje dodatkowe możliwości pomiarowe, ale także, jak każda metoda pomiarowa, posiada pewne ograniczenia. Do zalet systemu można zaliczyć $[13,15,16]$ :

- bezkontaktowość pomiaru,

- łatwość wykorzystania systemu w warunkach laboratoryjnych jak i polowych,

- możliwość pomiaru przemieszczeń i odkształceń zarówno na płaszczyźnie jak i w przestrzeni trójwymiarowej,

- uzyskanie powierzchniowych obrazów przemieszczeń i odkształceń,

- pomiar przemieszczeń i odkształceń jest możliwy we wszystkich kierunkach tj. wzdłuż osi $x, y, z$ w dowolnie przyjętym układzie współrzędnych,

- możliwość badania próbek o dowolnym kształcie i wykonanych z dowolnego materiału, badana powierzchnia próbki nie musi być płaska,

- możliwość pomiaru przemieszczeń i odkształceń próbek różnej wielkości, od mikropróbek badanych przy użyciu mikroskopu do obiektów wielkogabarytowych jak np. fragmenty mostów.

Najistotniejsze ograniczenia systemu to $[15,16]$ :

- konieczność przygotowania powierzchni próbki,

- konieczność wykorzystania sztucznego światła przy rejestracji obrazów z bardzo dużą częstotliwością,

- zależność systemu od warunków oświetlenia naturalnego,

- konieczność posiadania tablic kalibracyjnych odpowiednich do wielkości badanego obszaru próbki, 
- wysoka intensywność obliczeń i długi czas oczekiwania na końcowe wyniki badań,

- archiwizowanie zarejestrowanych obrazów i uzyskanych wyników badań wymaga pojemnych nośników pamięci,

- czasochłonne przegrywanie danych na nośniki pamięci.

Zastosowanie systemu cyfrowej korelacji obrazu 3D pozwala między innymi na $[13,14,15,16]$ :

- określenie dokładnego kształtu badanej próbki,

- badanie komponentów i materiałów w zakresie przemieszczeń i odkształceń,

- wyznaczenie współczynnika Poissona i modułu Younga badanego materiału,

- wykrywanie uszkodzeń, rys i pęknięć,

- pomiar drgań i analizę modalną,

- walidację modeli numerycznych MES.

W tabeli 1 przeprowadzono analizę porównawczą metody cyfrowej korelacji obrazu 3D oraz tradycyjnej metody pomiarowej z wykorzystaniem tensometrów.

Tabela 1. Porównanie metody cyfrowej korelacji obrazu 3D z pomiarami z zastosowaniem tensometrów $[13,17]$

Table 1. Comparison of 3D digital image correlation method with measurements by using tensometers $[13,17]$

\begin{tabular}{|l|l|}
\hline \multicolumn{1}{|c|}{ System cyfrowej korelacji obrazu 3D } & \multicolumn{1}{c|}{ Tensometry } \\
\hline Pomiar bezkontaktowy & Pomiar kontaktowy \\
\hline $\begin{array}{l}\text { Brak wpływu zmiany temperatury powierzchni } \\
\text { badanej próbki na sprzęt pomiarowy }\end{array}$ & $\begin{array}{l}\text { Wpływ temperatury powierzchni badanej } \\
\text { próbki na sprzęt pomiarowy }\end{array}$ \\
\hline $\begin{array}{l}\text { Wymagane dokładne oczyszczenie po- } \\
\text { wierzchni próbki przed badaniem }\end{array}$ & $\begin{array}{l}\text { Wymagane dokładne oczyszczenie po- } \\
\text { wierzchni próbki przed badaniem }\end{array}$ \\
\hline $\begin{array}{l}\text { Szybkie przygotowanie na powierzchni próbki } \\
\text { losowego wzoru czarnych kropek na białym } \\
\text { tle przez natryskiwanie farby }\end{array}$ & $\begin{array}{l}\text { Czasochłonny proces umieszczania na po- } \\
\text { wierzchni próbki tensometru (klejenie, luto- } \\
\text { wanie itp.) }\end{array}$ \\
\hline $\begin{array}{l}\text { Nieograniczona liczba pomiarów z wykorzy- } \\
\text { staniem systemu DIC }\end{array}$ & $\begin{array}{l}\text { Tensometr może być użyty jednorazowo (raz } \\
\text { naklejonych tensometrów nie da się odkleić } \\
\text { bez ich uszkodzenia) }\end{array}$ \\
\hline $\begin{array}{l}\text { Moźliwość pomiaru przemieszczeń i odkształ- } \\
\text { ceń na płaszczyźnie lub w przestrzeni trójwy- } \\
\text { miarowej, we wszystkich kierunkach (wzdłuż } \\
\text { osi } x, y, z \text { w dowolnym układzie współrzęd- } \\
\text { nych) }\end{array}$ & $\begin{array}{l}\text { Pomiar odkształceń tylko w wybranym kie- } \\
\text { runku }\end{array}$ \\
\hline $\begin{array}{l}\text { Chropowatość powierzchni nie ogranicza moż- } \\
\text { liwości pomiarowych systemu }\end{array}$ & $\begin{array}{l}\text { Powierzchnia, na którą naklejany jest tenso- } \\
\text { metr, musi być płaska }\end{array}$ \\
\hline $\begin{array}{l}\text { Uzyskanie powierzchniowych obrazów prze- } \\
\text { mieszczeń i odkształceń }\end{array}$ & $\begin{array}{l}\text { Uzyskanie wyników w wybranych punktach } \\
\text { próbki tj. tylko w punktach, w których przy- } \\
\text { mocowane zostały czujniki pomiarowe }\end{array}$ \\
\hline $\begin{array}{l}\text { Możliwość pomiaru rzeczywistych maksymal- } \\
\text { nych przemieszczeń i odkształceń }\end{array}$ & $\begin{array}{l}\text { Pomiar ograniczony przez graniczne odkształ- } \\
\text { cenie tensometru }\end{array}$ \\
\hline
\end{tabular}




\section{Zastosowanie systemu Q-450 do rejestracji i analizy pól przemieszczeń $\mathrm{i}$ odksztalceń $\mathrm{w}$ badaniach połączeń elementów konstrukcji stalowych}

System cyfrowej korelacji obrazu 3D Q-450 został wykorzystany na Wydziale Budownictwa, Inżynierii Środowiska i Architektury Politechniki Rzeszowskiej w badaniach połączeń spawanych i śrubowych elementów konstrukcji stalowych. Przebadano następujące elementy: kątowniki równoramienne łączone z blachami węzłowymi za pomocą jednej śruby [18] oraz kątowniki nierównoramienne łączone $\mathrm{z}$ blachami węzłowymi poprzez spawanie [19].

W przypadku połączeń śrubowych do badań wykorzystano elementy wykonane z kątowników równoramiennych o rozmiarach L50x5, L60x6 i L80x6 o długości $500 \mathrm{~mm}$ każdy, łączonych tym samym ramieniem do dwóch blach węzłowych (bl.10x100), za pomocą jednego łącznika śrubowego w każdym sty$\mathrm{ku}$. Próbki imitowały elementy konstrukcji wsporczych napowietrznych linii elektroenergetycznych wysokiego napięcia [18].

W przypadku połączeń spawanych próbki składały się ze stalowego walcowanego kształtownika o przekroju kątownika nierównoramiennego L80x40x6 długości $1 \mathrm{~m}$ połączonego za pomocą spoin na jedno ramię $\mathrm{z}$ dwoma blachami o wymiarach $250 \mathrm{~mm} \times 100 \mathrm{~mm}$ i grubości $8 \mathrm{~mm}$, które odpowiadały blachom węzłowym. Próbki imitowały elementy konstrukcji kratowych takie jak wiązary dachowe czy płatwie [19].

Celem badania było uzyskanie map przemieszczeń i odkształceń w obszarze połączenia kształtowników z blachą węzłową za pomocą systemu cyfrowej korelacji obrazu, które mogą zostać wykorzystane do analizy i oceny nośności połączeń oraz posłużyć do walidacji modeli numerycznych.

Pierwszym etapem badania było przygotowanie w odpowiedni sposób powierzchni próbek. Kształtowniki i blachy węzłowe zostały dokładne oczyszczone w obrębie badanego obszaru połączenia. Na próbki naniesiono biały podkład, a następnie metodą natryskiwania wykonano na białej powierzchni losowy wzór punktów. Zagęszczenie wzoru zostało dostosowane do wielkości badanego obszaru. Etapy przygotowania próbek do badania systemem cyfrowej korelacji obrazu Q-450 przedstawiono na Rys. 4. 


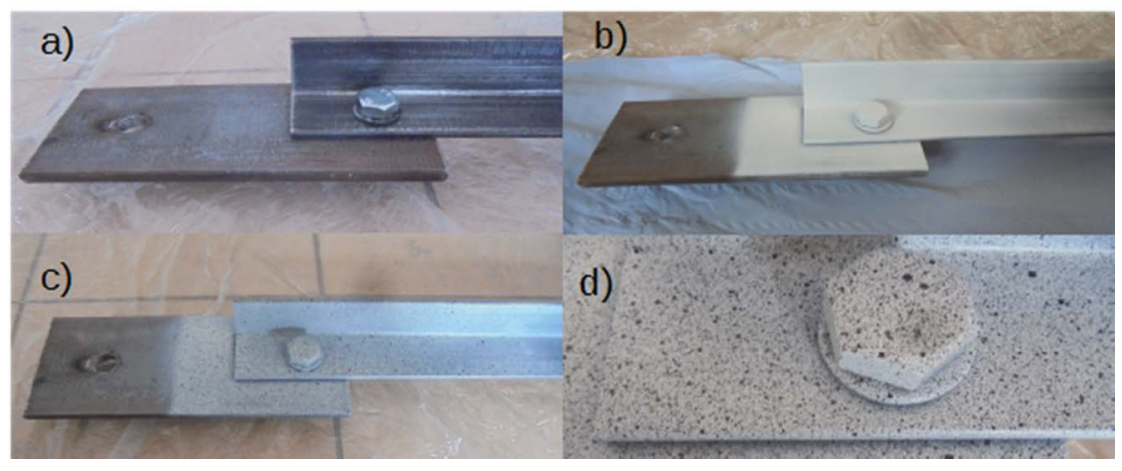

Rys. 4. Przygotowanie próbki do badania - oczyszczenie powierzchni (a), nałożenie białego podkładu (b), naniesienie czarnych kropek (b), efekt końcowy (d)

Fig. 4. Sample preparation for test - cleaning of the surface (a), applying white underlay (b), applying black dots (b), the final result (d)

Najczęstszym błędem popełnianym podczas przygotowania próbki jest niewłaściwe oczyszczenie powierzchni (przy spodziewanych dużych odkształceniach próbki bardzo ważne jest, aby przyczepność farby do powierzchni próbki była jak największa, inaczej naniesiony wzór prawdopodobnie ulegnie zniszczeniu podczas obciążania obiektu (Rys. 5)) oraz naniesienie zbyt dużej ilości białego podkładu, przez co powierzchnia staje się błyszcząca i odbija światło, a w konsekwencji jest pomijana w dalszej analizie.

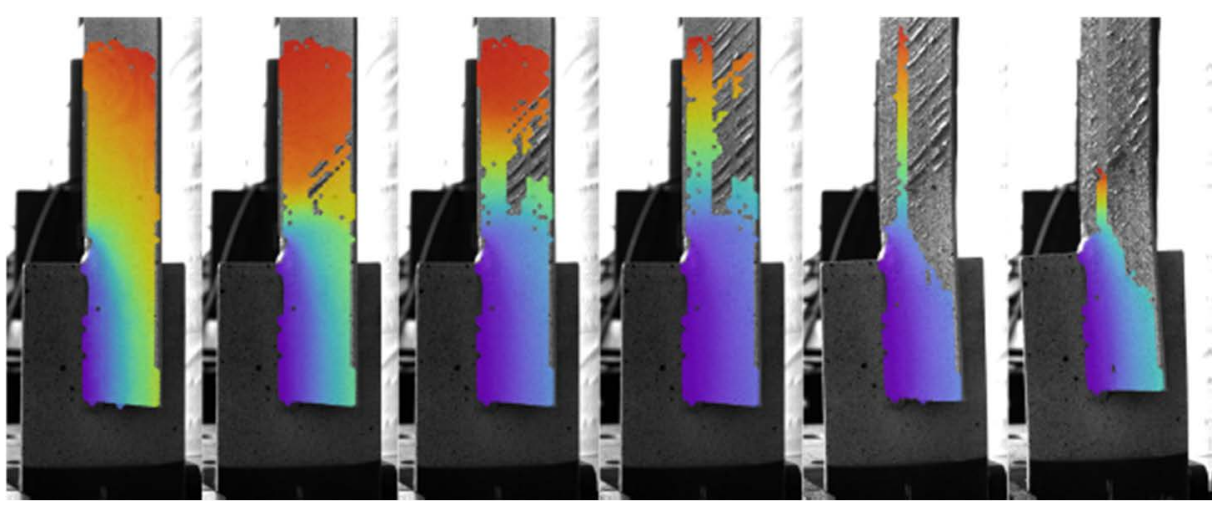

Rys. 5. Zmniejszenie analizowanego obszaru spowodowane utratą wzoru na powierzchni próbki

Fig. 5. Reduction of the analyzed sample area due to the loss of the pattern on the sample surface

Zagęszczenie i wielkość wzoru na powierzchni próbki powinny być odpowiednio dobrane do wielkości badanego obszaru próbki tak, aby w każdym regionie korelacji, wyznaczonym w programie Istra 4D na obrazie referencyjnym badanego obiektu, znajdował się charakterystyczny fragment biało-czarnego 
wzoru. Z kolei wielkość badanego obszaru wpływa na wybór tablicy kalibracyjnej służącej do kalibracji systemu. Tablica dobierana jest do rozmiaru badanego obszaru w taki sposób, aby wzór szachownicy znajdujący się na tablicy wypełniał w pełni obraz w każdej kamerze wykorzystanej do pomiarów.

Drugim etapem badań było przygotowanie stanowiska pomiarowego, w tym odpowiednie ustawienie kamer. Obiekt powinien być obserwowany przez kamery z dwóch kierunków. Kamery należy ustawić tak, aby badany obszar znajdował się centralnie w środku pola widzenia obu kamer, a kąt między kamerami powinien wynosić od 40 do 60 stopni [12]. Bardzo ważną kwestią przy przygotowywaniu stanowiska pomiarowego jest zapewnienie prawidłowego oświetlenia badanego obiektu. Korzystanie z oświetlenia naturalnego zalecane jest przy krótkich pomiarach oraz przy pomiarach z niską częstotliwością rejestracji obrazów. Przy długich pomiarach, aby uzyskać stabilne warunki oświetlenia, korzystne jest zastosowanie sztucznego oświetlenia np. lamp ksenonowych, oświetlenia stroboskopowego czy ultra jasnego LED. Oświetlenie sztuczne stosuje się również przy pomiarach $\mathrm{z}$ dużą częstotliwością rejestracji obrazów, gdyż oświetlenie naturalne jest w takich przypadkach zazwyczaj niewystarczające.

Stanowisko pomiarowe do badań laboratoryjnych składało się z maszyny wytrzymałościowej firmy INSTRON oraz z systemu cyfrowej korelacji obrazu 3D Q-450. W badaniu wykorzystano dwie kamery cyfrowe Phantom v341, zamocowane na oddzielnych statywach oraz obiektywy z ogniskową $50 \mathrm{~mm}$. Podczas pomiarów nie wykorzystywano sztucznego oświetlenia, gdyż oświetlenie naturalne było stabilne i wystarczające dla zapewnienia odpowiednich warunków badania. Stanowisko laboratoryjne przedstawiono na Rys. 6 .

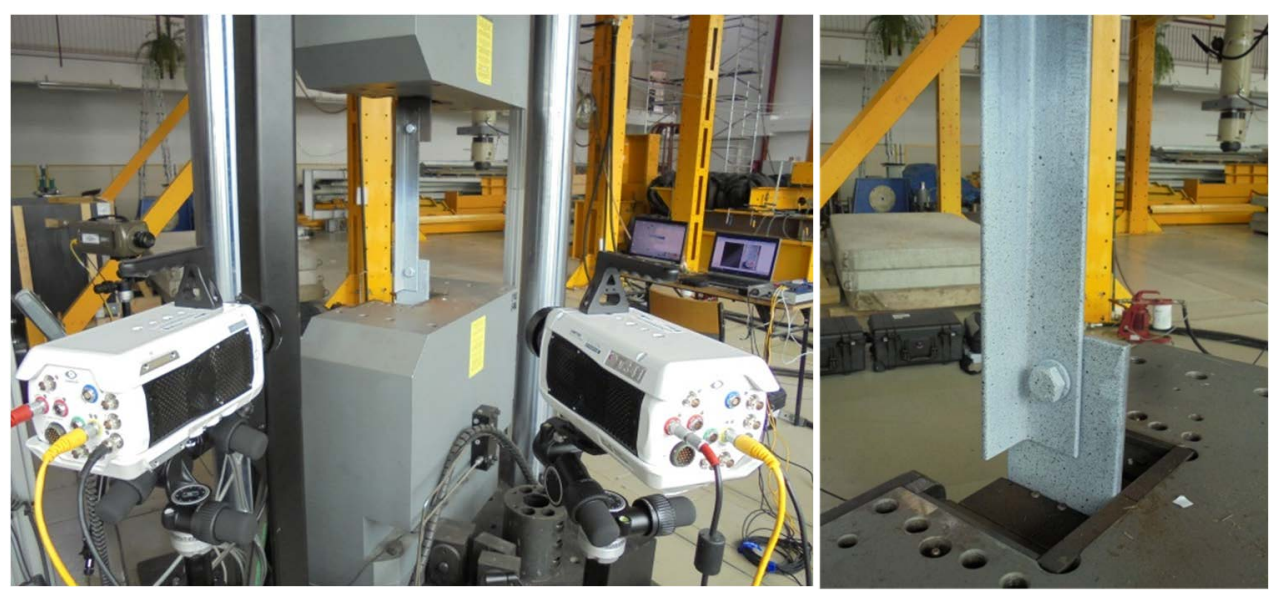

Rys. 6. Stanowisko pomiarowe

Fig. 6. Measurement set-up 
Kolejnym etapem pomiaru przemieszczeń i odkształceń połączeń elementów konstrukcji stalowych była kalibracja systemu. Kalibrację wykonuje się przy pomocy specjalnie przeznaczonych do tego tablic kalibracyjnych. Proces kalibracji polega na zarejestrowaniu minimum ośmiu obrazów tablicy kalibracyjnej umieszczonej w polu widzenia kamer w różnych położeniach. Zalecane pozycje tablicy w czasie kalibracji systemu Q-450 przedstawiono na Rys. 7 [12, 13]. System oblicza wewnętrzne i zewnętrzne parametry kalibracji, których ustalenie jest niezbędne do analizy geometrii obiektu i przeniesienia wszystkich punktów z obrazów zarejestrowanych przez kamery z płaszczyzny do przestrzeni. Wewnętrzne parametry kalibracji ustalane podczas kalibracji systemu DIC to długość ogniskowej $f\left(f_{x}, f_{y}\right)$, punkt główny $P P\left(x_{0}, y_{0}\right)$ oraz składowe dystorsji. Zewnętrzne parametry kalibracji określają pozycję kamery w odniesieniu do wstępnego układu współrzędnych ustalonego na podstawie pierwszego zarejestrowanego obrazu tablicy kalibracyjnej w procesie kalibracji. Zewnętrzne parametry kalibracji to wektor przesunięcia $T\left(T_{x}, T_{y}, T_{z}\right)$ oraz wektor rotacji $R\left(R_{x}, R_{y}, R_{z}\right)$.

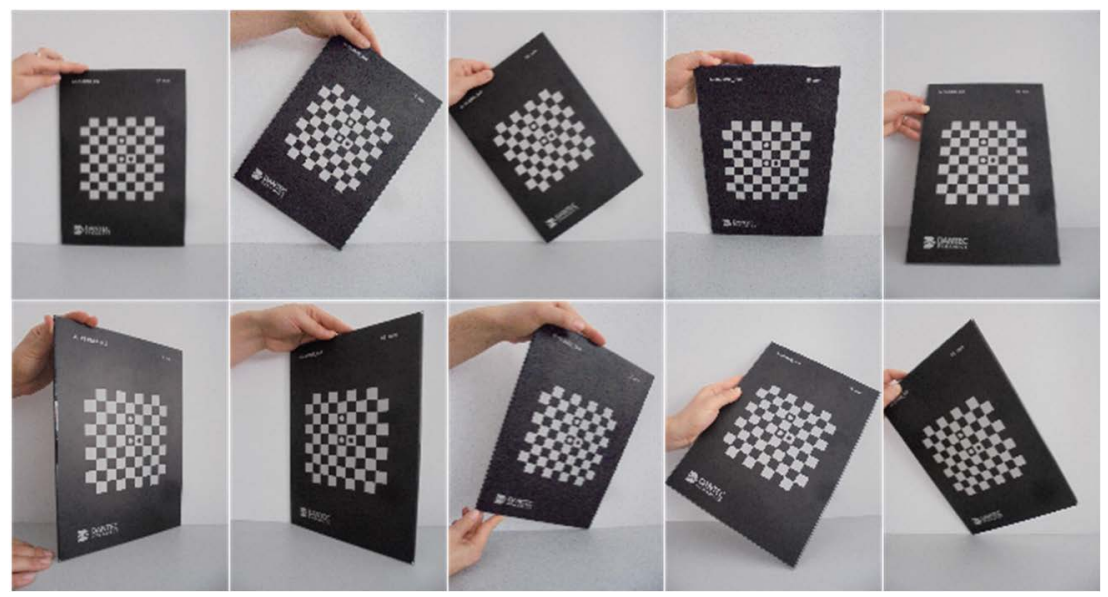

Rys. 7. Zalecane pozycje tablicy kalibracyjnej w procesie kalibracji

Fig. 7. Recommended positions of the calibration target during the calibration process

Proces kalibracji można wykonywać na kilka sposobów. Najczęściej wykonuje się kalibrację dwóch kamer jednocześnie tzw. kalibrację pełna. W niektórych przypadkach konieczne jest niezależne ustalenie parametrów wewnętrznych i zewnętrznych kalibracji albo wykonanie kalibracji oddzielnie dla każdej kamery. Kalkulacja parametrów kalibracji odbywa się za pomocą algorytmu optymalizacji, który określa średnią niedokładność odnalezionych na zarejestrowanych obrazach znaczników (narożników kwadratów szachownicy tablicy kalibracyjnej) w jednostce pikseli, tzw. residuum. Wartość ta jest miarą niedokładności obliczanych parametrów czyli parametrem jakości procesu kalibracji i powinna 
być mniejsza od wartości 0,3 do $0,5 \mathrm{w}$ zależności od rodzaju zastosowanej tablicy kalibracyjnej. Wartość residuum powyżej 1,0 oznacza pojawienie się błędu podczas kalibracji i w takim przypadku proces kalibracji należy powtórzyć [12]. Najczęstszym błędem popełnianym przy kalibracji jest nieodpowiednie pozycjonowanie tablicy, a także niezapewnienie prawidłowego oświetlenia tablicy lub nieprawidłowe ustawienie ostrości obiektywu. Ilekroć zmieniane jest położenie kamer albo ustawienia obrazu (ostrość, przesłona), należy przeprowadzić nową kalibrację. Jak już wcześniej wspomniano domyślny układ współrzędnych w programie Istra 4D, w którym wyznaczane są wartości przemieszczeń i odkształceń, określany jest podczas procesu kalibracji na podstawie pierwszego zdjęcia tablicy kalibracyjnej, dlatego ważne jest dokładne ustawienie pożądanego położenia tablicy na etapie rejestracji pierwszego zdjęcia.

Do kalibracji systemu zastosowano tablicę kalibracyjną o wymiarach $21 \mathrm{~cm} \times 30 \mathrm{~cm}$. Wykonano kalibrację pełną. Uzyskane wartości parametrów kalibracji przedstawiono na Rys. 8. Wartość residuum była prawidłowa i wyniosła 0,112 piksela.

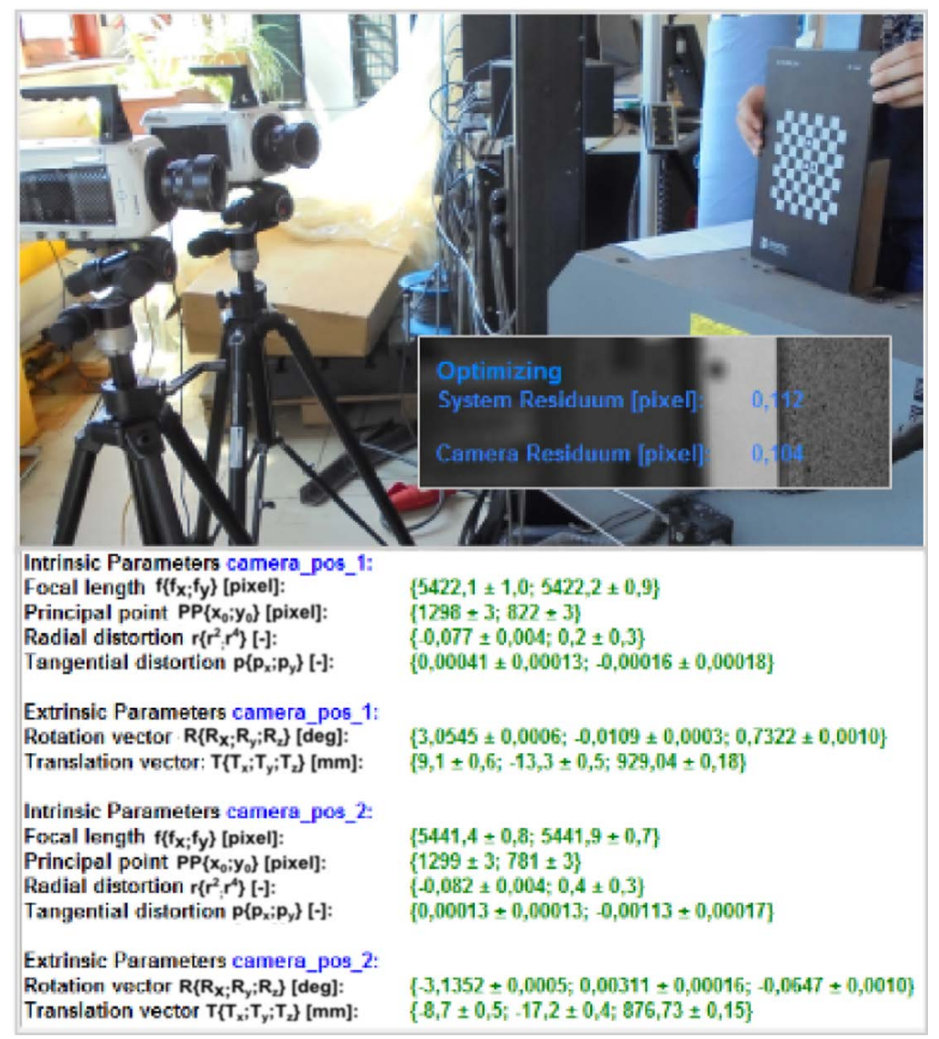

Rys. 8. Parametry kalibracji systemu DIC

Fig. 8. Calibration parameters of DIC system 
Kolejnym etapem badania była rejestracja obrazów. Obrazy rejestrowane podczas jednego pomiaru tworzą pojedynczą serię danych. Obrazy można rejestrować w sposób manualny lub w sposób ciągły z wybraną stałą częstotliwością do bufora pamięci kamery (o pojemności 32 GB). Pomiar przemieszczeń i odkształceń kształtowników stalowych łączonych za pomocą jednej śruby oraz łączonych poprzez spawanie przeprowadzono podczas statycznej próby rozciągania. Rejestracja obrazów przeprowadzona została w sposób ciągły z częstotliwością $1 \mathrm{~Hz}$. Obrazy uzyskano w każdej sekundzie badania.

Zarejestrowane systemem Q-450 obrazy badanych połączeń zostały następnie przeanalizowane $\mathrm{w}$ programie Istra 4D. Specjalistyczne oprogramowanie analizuje kolejno zapisane w czasie obciążania próbki obrazy serii pomiarowej, jest to tzw. proces ewaluacji danych. Proces ten polega na wyznaczeniu przestrzennych współrzędnych badanego obiektu dla każdego pojedynczego kroku pomiarowego, a więc obrazu zarejestrowanego przez każdą z kamer, w oparciu o parametry kalibracji wyznaczone w procesie kalibracji oraz ustalone przez użytkownika parametry korelacji obrazu.

Użytkownik systemu poprzez modyfikację parametrów korelacji może wpływać na szybkość i dokładność procesu korelacji. Parametry, które można definiować w programie Istra 4D, to wielkość okna korelacji Facet Size, liczba poziomów rozkładu przestrzennego Image Levels oraz poziom tolerancji Outlier Tolerance. Wielkość okna korelacji wyrażana jest w pikselach. Minimalny wymiar okna korelacji jest ściśle powiązany z rozmiarem stochastycznego wzoru na badanej powierzchni próbki (każdy region korelacji musi zawierać charakterystyczną część wzoru o kontrastowych cechach). Zwiększenie wymiaru regionu korelacji obniża dokładność pomiarów, ale skraca czas procesu korelacji obrazów. Liczba poziomów Image Levels również wpływa na szybkość i dokładność korelacji, im większa liczba poziomów rozkładu przestrzennego, tym proces korelacji jest dłuższy, ale dokładniejszy, mniejsza liczba poziomów zwiększa szybkość korelacji, ale równocześnie zwiększa ryzyko uzyskania nieprawdziwych wyników. Parametr tolerancji Outlier Tolerance może być niski, wysoki lub średni. Wysoki i średni poziom tolerancji znacząco wydłuża proces korelacji, ale jest zalecany dla obrazów złej jakości, z refleksami. Przy wysokim poziomie tolerancji zakłócenia na obrazie w postaci prześwietleń mają niewielki wpływ na wynik korelacji. W procesie korelacji określana jest również odległość (wyrażana $\mathrm{w}$ pikselach) między punktami wirtualnej siatki nałożonej w programie na obraz próbki. Rozmiar okna wirtualnej siatki determinuje dokładność pomiarów. Im gęściejsza jest siatka, tym więcej jest punktów pomiarowych na analizowanej powierzchni badanego obiektu. Wymiar regionu korelacji powinien odpowiadać $4 / 3$ odległości między punktami wirtualnej siatki.

Użytkownik systemu Q-450 może wybrać predefiniowane zestawy parametrów korelacji: zaawansowany Advanced - Full User Defined - wszystkie ustawienia mogą być definiowane przez użytkownika, normalny Normal-Good Images - domyślny zestaw parametrów dla obrazów dobrej jakości, normalny 
Normal-Bad Images - domyślny zestaw parametrów dla obrazów złej jakości (z refleksami), szybki Fast - zestaw parametrów optymalizujący szybkość korelacji kosztem jakości oraz zestaw parametrów wysokiej jakości High Accuracy optymalizujący dokładność korelacji kosztem szybkości.

W badaniach połączeń elementów konstrukcji stalowych wybrano zestaw parametrów korelacji Normal-Good Images (Rys. 9). Przy tak zdefiniowanych parametrach korelacji przeprowadzono proces ewaluacji obrazów zarejestrowanych podczas obciążania próbek.

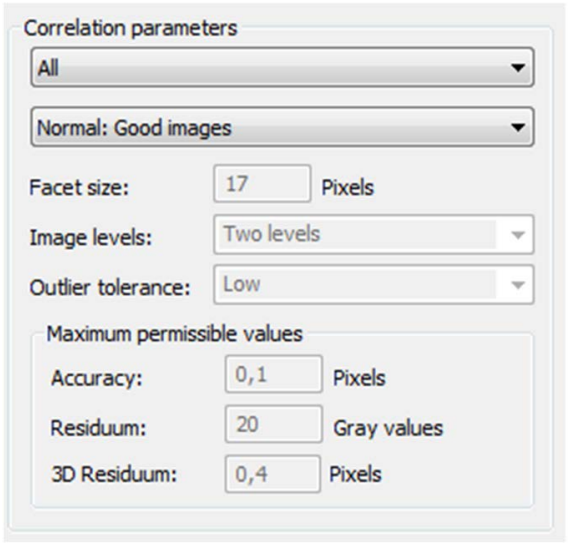

Rys. 9. Parametry korelacji

Fig. 9. Corelation parameters

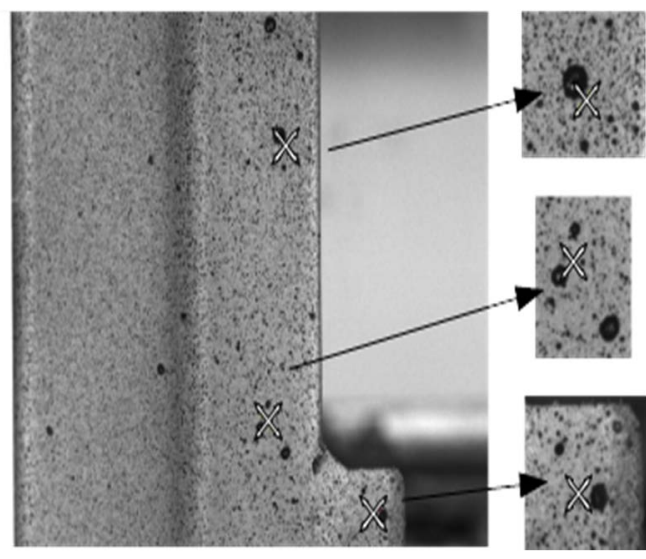

Rys. 10. Rozmieszczenie punktów startowych w charakterystycznych miejscach losowego wzoru

Fig. 10. Location of the Startpoints in characteristic fragment of the random pattern

Proces ewaluacji odbywał się dwuetapowo. Pierwszy etap to ewaluacja częściowa, która polega na wskazaniu przez użytkownika systemu charakterystycznych punktów na badanej powierzchni - tzw. punktów startowych (ang. startpoints) oraz automatycznym odnajdywaniu przez program tych punktów na kolejnych obrazach serii pomiarowej. Proces korelacji ogranicza się więc na tym etapie tylko do konkretnych punktów badanego obszaru. Drugi etap ewaluacji to ewaluacja pełna, a więc obejmująca wszystkie punkty obrazu [12]. Trudność dla użytkownika systemu może stanowić dobór odpowiednich punktów startowych. Punkty należy wybierać w charakterystycznych miejscach losowego wzoru nieniesionego na próbkę, jak pokazano na Rys. 10, należy także pamiętać, że źle ustawiona ostrość, niewłaściwe oświetlenie próbki (zbyt ciemny albo prześwietlony obraz) lub umieszczanie punktów startowych na fragmentach obrazu, w obrębie których na dalszych zdjęciach serii pomiarowej utracony zostaje losowy wzór, może spowodować zatrzymanie procesu ewaluacji. 
Ostatnim etapem badań połączeń elementów konstrukcji stalowych systemem cyfrowej korelacji obrazu była analiza i wizualizacja wyników. Program Istra 4D pozwala na wyznaczenie konturu przestrzennego badanego obiektu, przemieszczeń na kierunkach $x, y, z$, przemieszczenia całkowitego, wartości odchyleń standardowych dla poszczególnych przemieszczeń, odkształceń stycznych na kierunkach $x$ i $y$, odkształcenia kątowego, odkształceń na kierunkach głównych oraz wartości odchyleń standardowych dla poszczególnych wartości odkształceń, dla każdego analizowanego punktu próbki. Obliczone przez program wartości przemieszczeń i odkształceń można eksportować do plików zewnętrznych lub przestawić w postaci kolorowych map. Wizualizacja wyników w programie Istra 4D może odbywać się na płaszczyźnie lub w przestrzeni trójwymiarowej. Program daje możliwość definiowania na analizowanej powierzchni badanego obiektu punktów, linii oraz obszarów o różnym kształcie, dla których można uzyskać dodatkowe informacje np. dla dowolnie wybranego punktu wyznaczyć wykres przedstawiający zmianę przemieszczenia lub odkształcenia w czasie. Istotną kwestią na etapie wizualizacji jest dobór układu współrzędnych, w odniesieniu do którego będą obliczane wartości przemieszczeń i odkształceń [12]. Należy pamiętać, że za domyślny układ współrzędnych program przyjmuje układ zdefiniowany na podstawie pierwszego zdjęcia tablicy kalibracyjnej $\mathrm{w}$ procesie kalibracji. Wstępnie przyjęty przez program układ współrzędnych można jednak zmieniać, program Istra 4D daje bowiem możliwość definiowania własnego układu współrzędnych. Warto zaznaczyć, że wszystkie wartości przemieszczeń i odkształceń dla pozostałych obrazów w serii pomiarowej są obliczane w odniesieniu do wartości uzyskanych dla wybranego na etapie wizualizacji obrazu referencyjnego.

Oprogramowanie systemu cyfrowej korelacji obrazu stanowi jego integralną część zawierającą moduły obliczeniowe, w przypadku których ocena ich działania i modyfikacja nie jest możliwa [8]. Dla wyznaczonych wartości przemieszczeń i odkształceń program Istra 4D automatycznie podaje wartości błędów pomiarowych. Dokładność algorytmu korelacji wynosi około 0,01 piksela, jest więc ona ściśle związana z rozdzielczością obrazów [13, 16].

$\mathrm{Na}$ Rys. 11 przedstawiono przykładowe mapy przemieszczeń uzyskane z badań kątowników łączonych za pomocą jednej śruby. Są to przemieszczenia pionowe (w kierunku rozciągania próbki) w różnych fazach wytężenia kątownika (po $600 \mathrm{~s}$ rozciągania próbki, w $1800 \mathrm{~s}$ badania oraz w chwili zniszczenia próbki tj. w $3596 \mathrm{~s}$ badania). Mapy zostały zaprezentowane w płaskim układzie odniesienia (Rys. 11a) oraz w układzie przestrzennym (Rys. 11b). Rysunek 12 przedstawia mapy odkształceń głównych wraz z kierunkami głównymi pokazane w przestrzennym układzie odniesienia w chwili rozpoczęcia badania, po $1800 \mathrm{~s}$ oraz w chwili zakończenia badania tj. w $3596 \mathrm{~s}$. 
a)

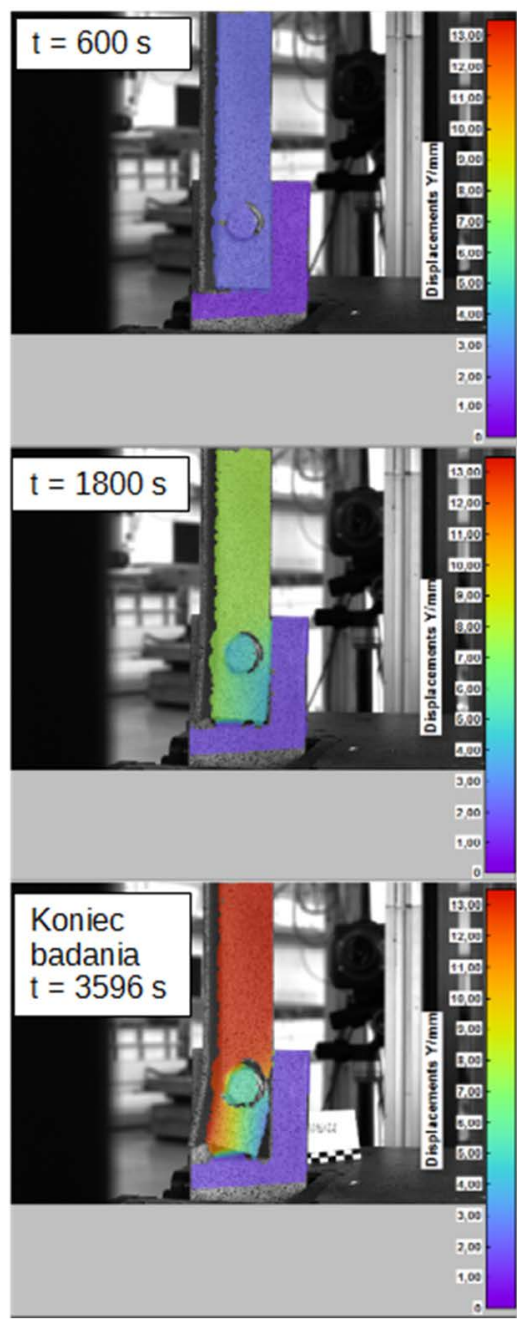

b)

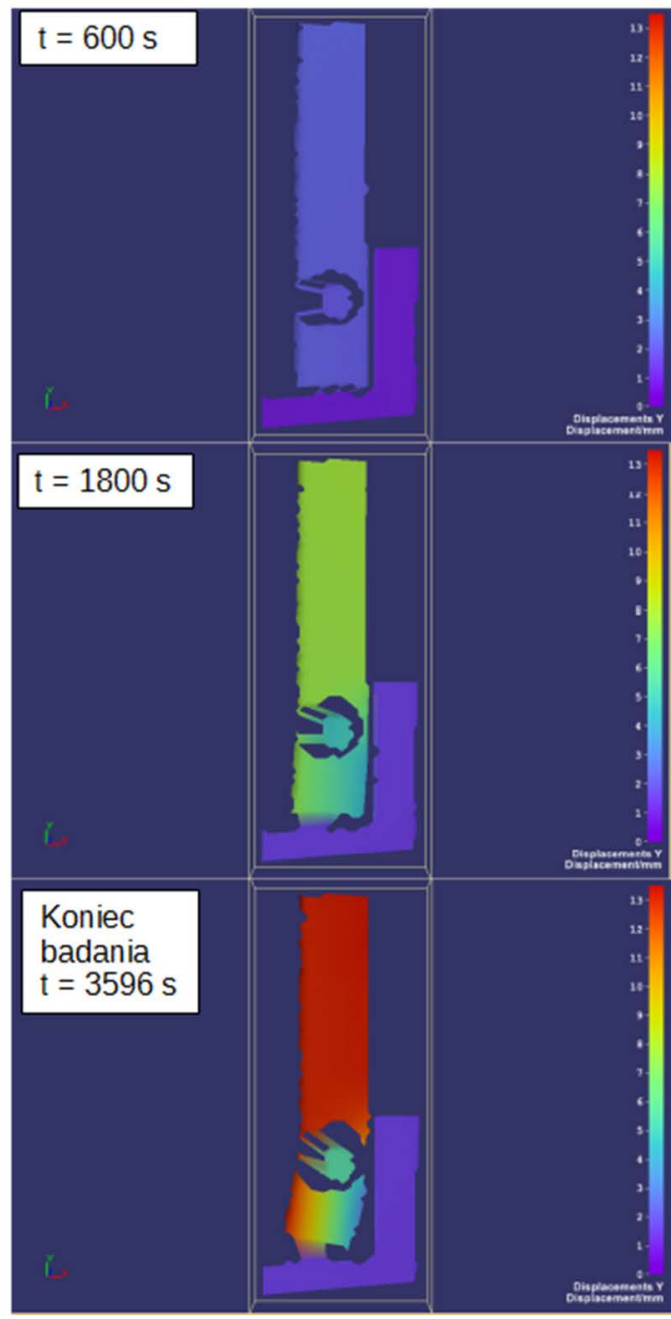

Rys. 11. Mapy przemieszczeń w kierunku osi podłużnej próbki - w płaskim układzie odniesienia (a), w przestrzennym układzie odniesienia (b)

Fig. 11. Displacement maps in the direction of the longitudinal axis of the sample - in the plane reference system (a), in the spatial reference system (b)

W badaniach wykorzystano również funkcję ekstensometru. Rysunek 13 przedstawia zdefiniowany liniowy element (o długości $100 \mathrm{~mm}$ ) dla którego zastosowano funkcję ekstensometru oraz wygenerowany w programie Istra 4D wykres zmiany odległości między dwoma wybranymi punktami próbki (początek i koniec elementu liniowego) w czasie obciążania próbki. 


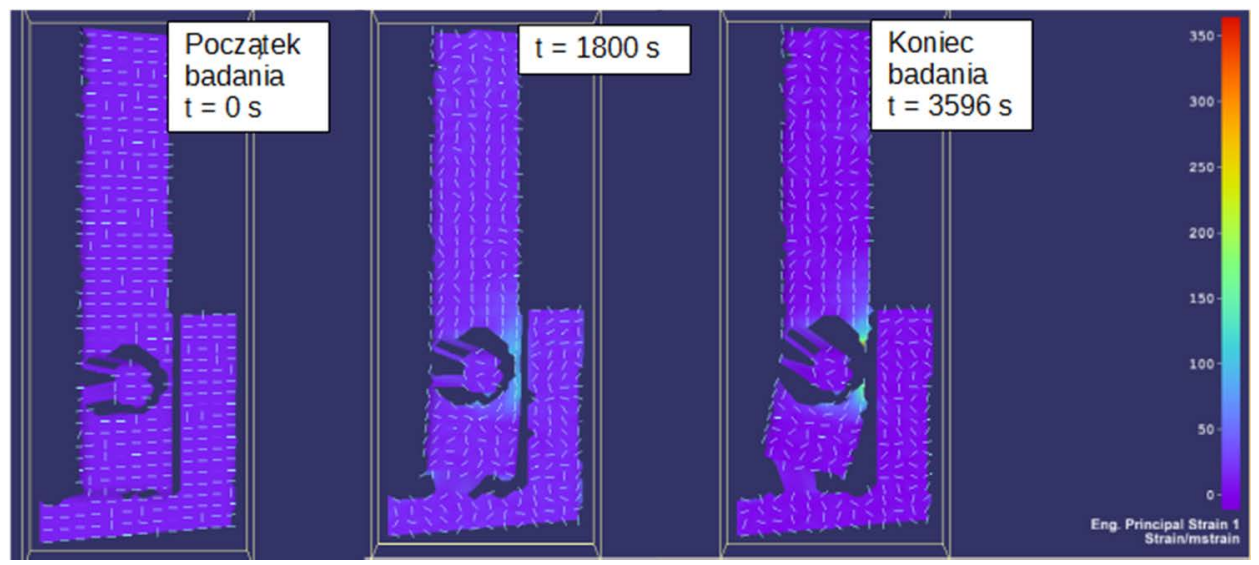

Rys. 12. Mapy odkształceń głównych

Fig. 12. Principal strain maps
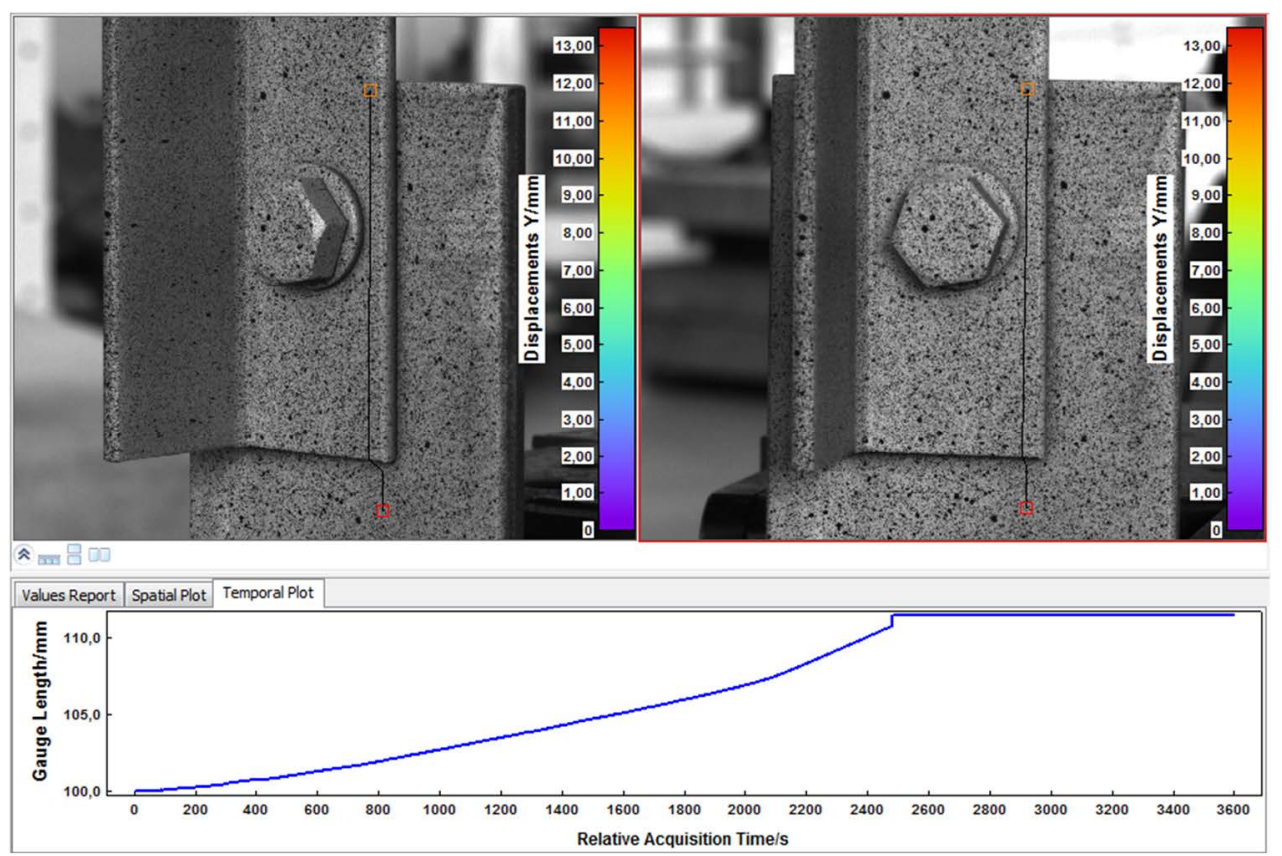

Rys. 13. Element liniowy zdefiniowany w programie Istra 4D i wykres zmiany długości tego elementu w czasie

Fig. 13. Linear element defined in the Istra $4 \mathrm{D}$ and the temporal plot of the linear element length

Poniżej przedstawiono przykładowe wyniki pomiaru otrzymane z badań kątowników łączonych poprzez spawanie. Zniszczenie próbki nastąpiło w $2320 \mathrm{~s}$ badania, a maksymalne wartości odkształceń próbka uzyskała w $2318 \mathrm{~s}$. 

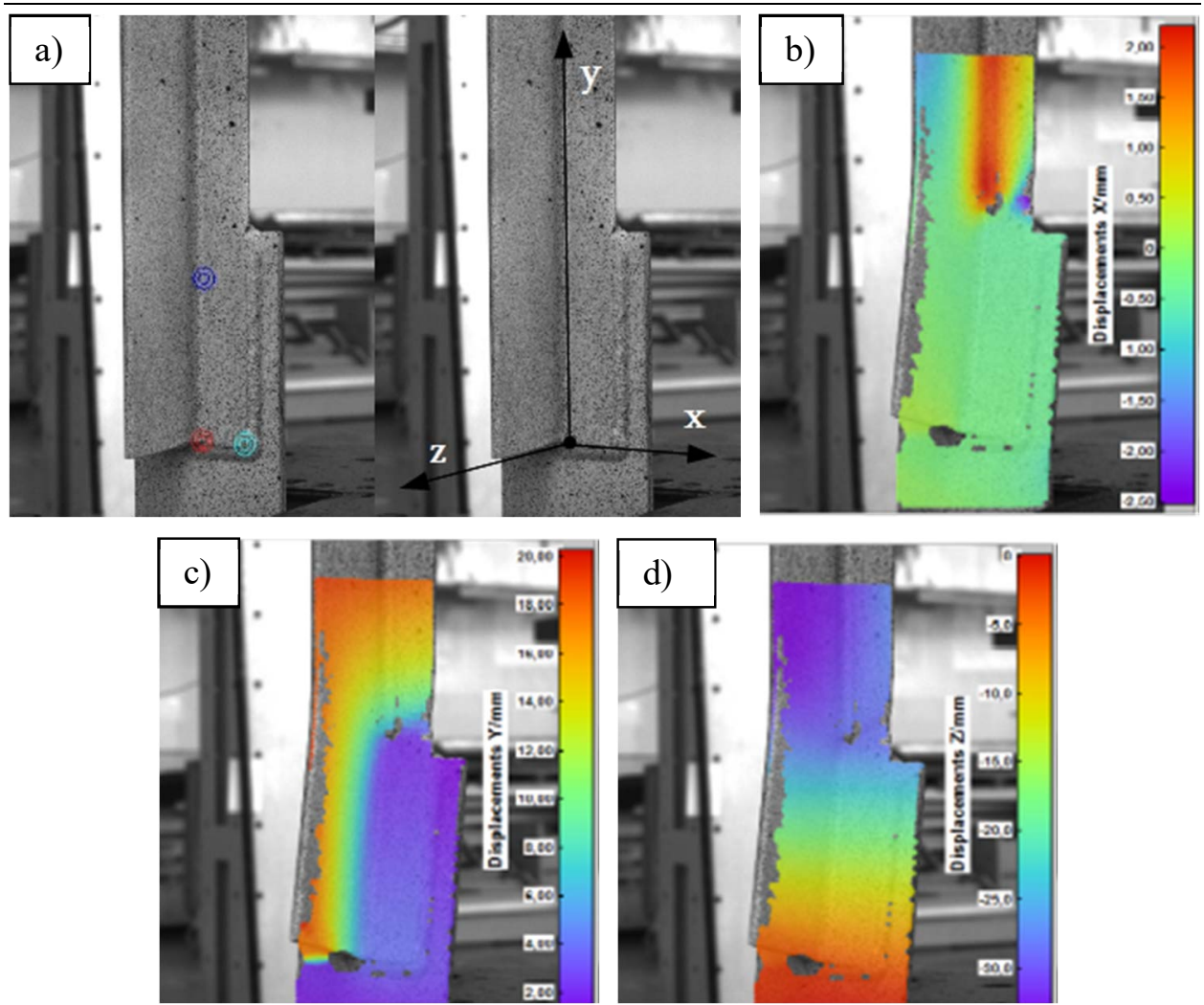

Rys. 14. Mapy przemieszczeń w układzie osi $x y z$ - układ współrzędnych zdefiniowany w programie Istra 4D (a), przemieszczenia $x(\mathrm{~b})$, przemieszczenia $y(\mathrm{c})$, przemieszczenia $z(\mathrm{~d})$

Fig. 14. Displacement maps in coordinate system $x y z$ - ucoordinate system defined in Istra 4D Istra 4D (a), $x$ displacement (b), $y$ displacement (c), $z$ displacement (d)

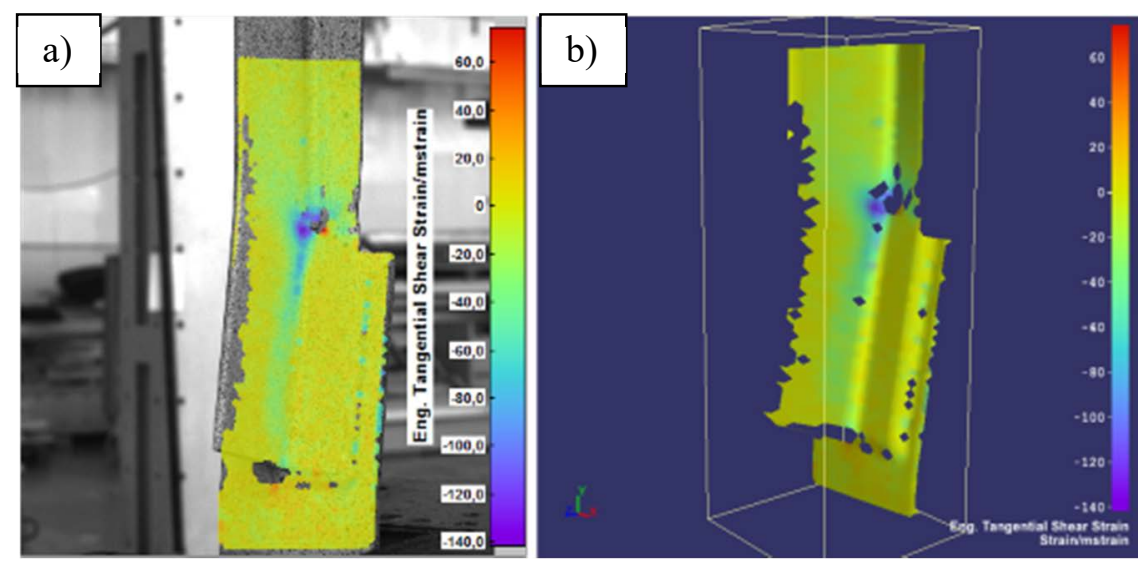

Rys. 15. Mapa odkształcenia kątowego $w$ chwili $t=2318 s-2 D(a), 3 D(b)$

Fig. 15. Tangential Shear Strain for $t=2318 s-2 D(a), 3 D(b)$ 
Na Rys. 14 przedstawiono zdefiniowany w programie Istra 4D układ współrzędnych, w którym odczytano wyniki badań oraz mapy przemieszczeń na kierunkach $x, y, z$ w $2318 \mathrm{~s}$ badania. Na Rys. 15 przedstawiono mapę odkształcenia kątowego w chwili $\mathrm{t}=2318 \mathrm{~s}$.

Następnie zawężono analizę pól przemieszczeń i odkształceń do obszaru samej spoiny podłużnej. Na Rys. 16 pokazano analizowany obszar próbki, mapę przemieszczeń w kierunku osi $y$ dla spoiny podłużnej próbki oraz porównano przemieszczenia $y$ wybranych punktów spoiny w czasie.
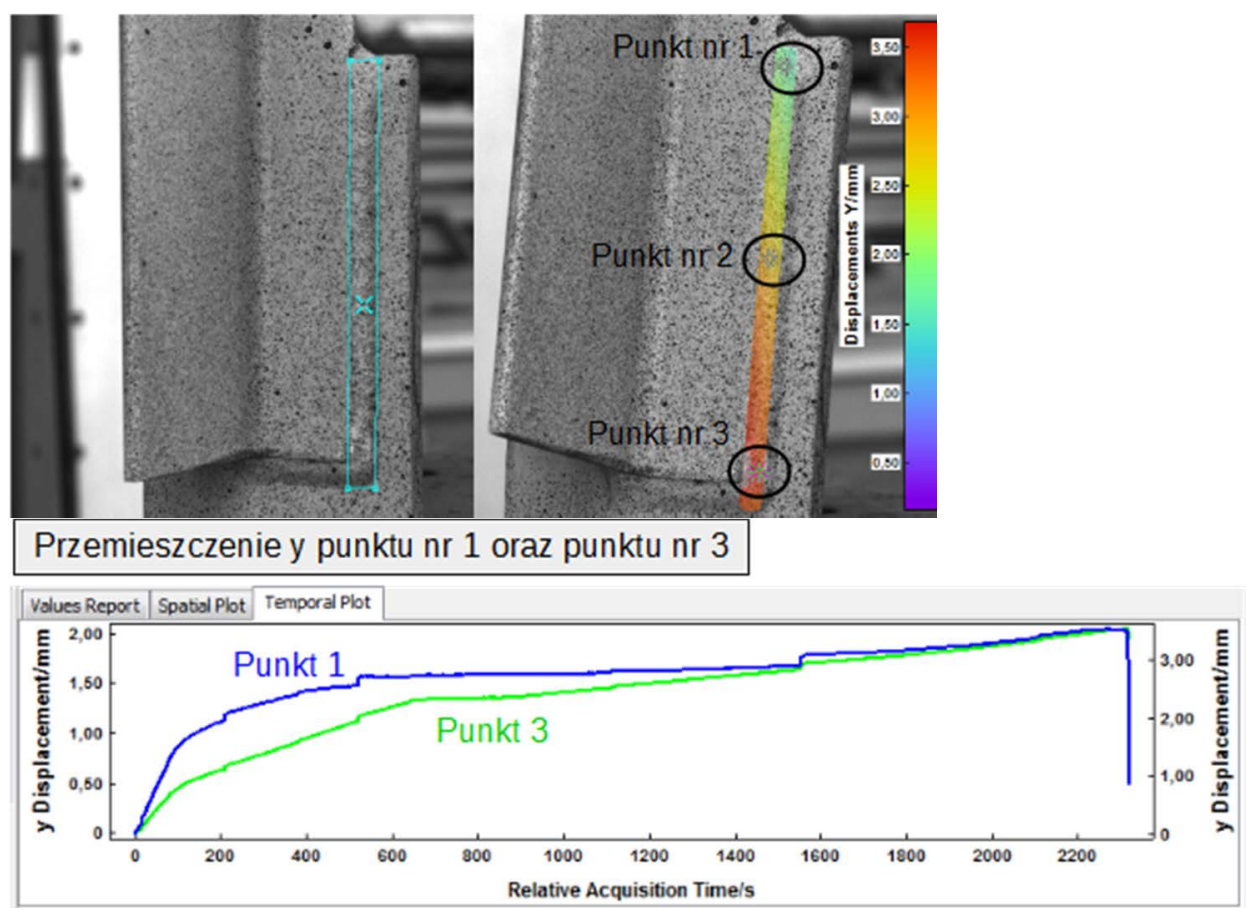

Przemieszczenie y punktu $\mathrm{nr} 2$ oraz punktu $\mathrm{nr} 3$

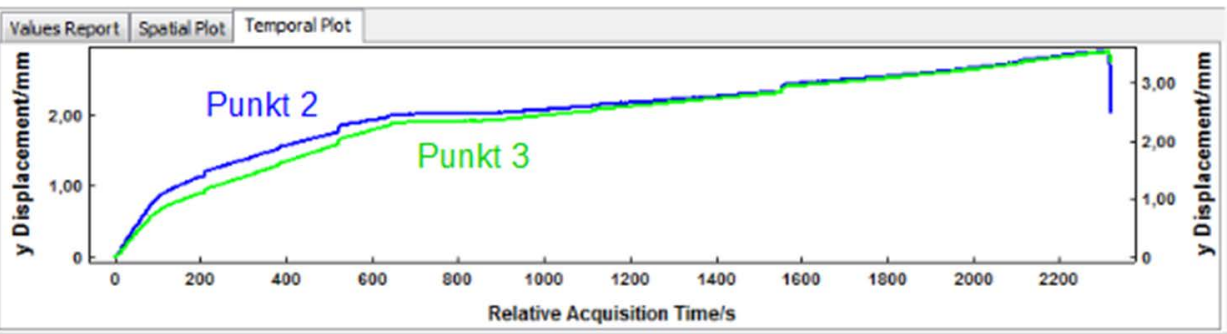

Rys. 16. Analiza przemieszczeń w obszarze spoiny

Fig. 16. Analysis of displacement in the weld area 
Analizując pola przemieszczeń i odkształceń można zaobserwować inicjację zniszczenia próbki. Miejsca koncentracji odkształceń stycznych y zaobserwowano w okolicy spoiny poprzecznej oraz krótszego ramienia kątownika powyżej połączenia z blachą, w narożu kątownika, co widać na mapach odkształceń przedstawionych na Rys. 17.
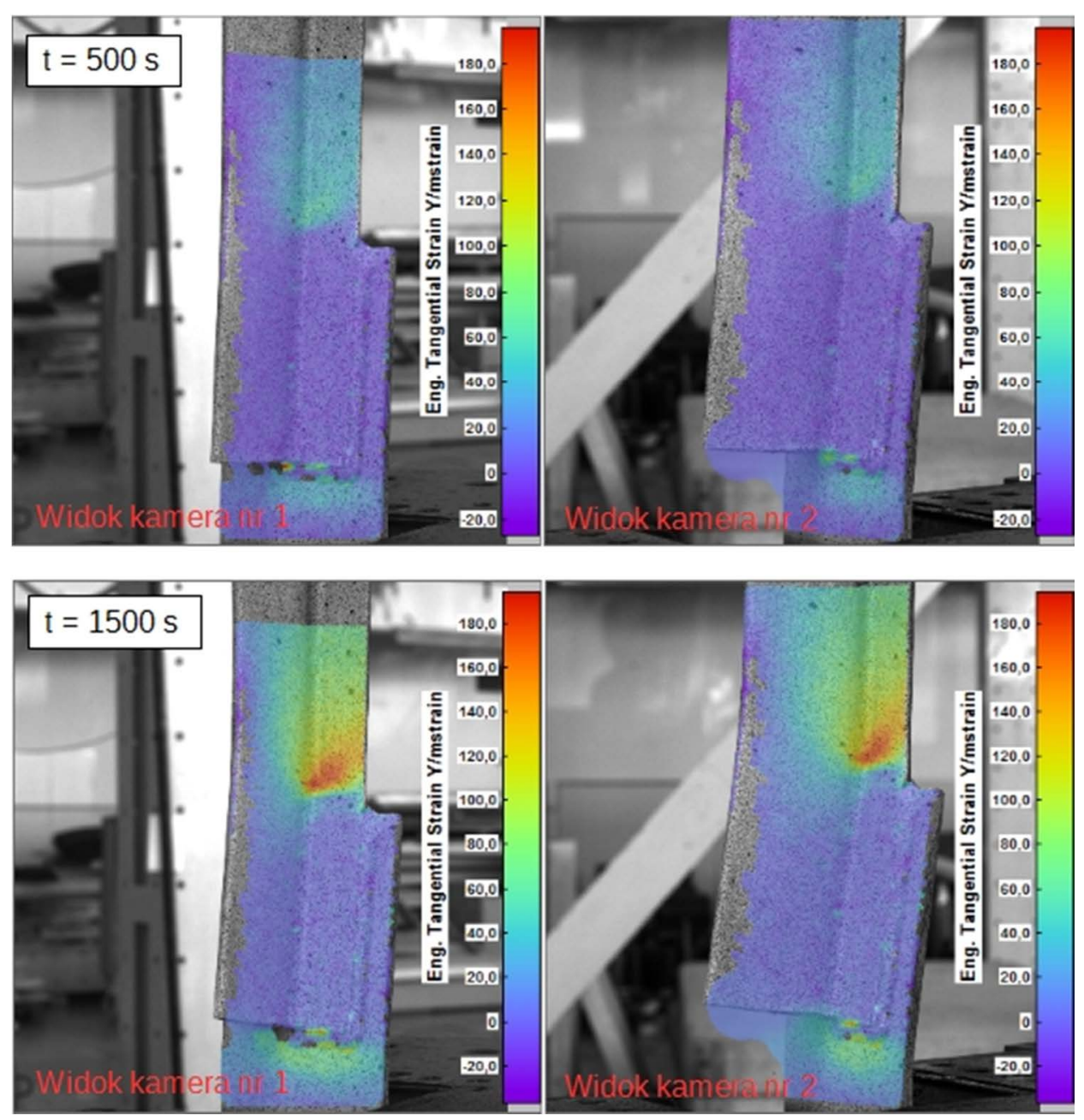

Rys. 17. Inicjacja zniszczenia próbki

Fig. 17. Initiation of sample destruction

Na Rys. 18 pokazano deformację badanego obiektu w przestrzeni trójwymiarowej. Zielona siatka nałożona na obiekt obrazuje stan próbki przed deformacją, czerwona siatka pokazuje postać zdeformowaną próbki. Rysunek został wyeksportowany z programu Istra 4D. 

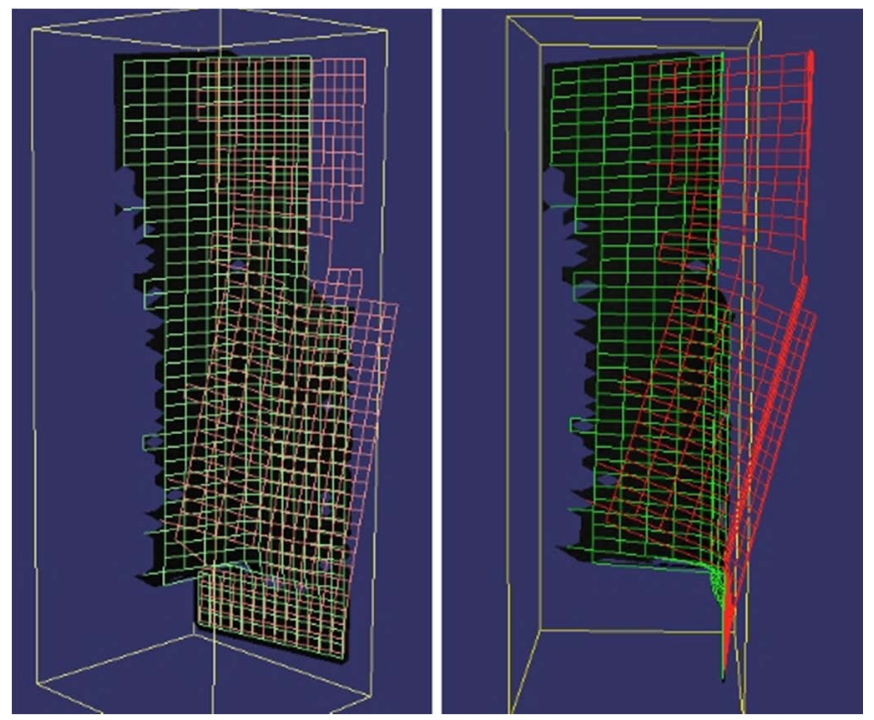

Rys. 18. Deformacja próbki w 3D - widok z dwóch kamer

Fig. 18. 3D sample deformation - view from two cameras

\section{Podsumowanie}

System cyfrowej korelacji obrazu daje nowe możliwości badawcze w zakresie pomiaru przemieszczeń i odkształceń w stosunku do tradycyjnych metod pomiarowych. Metoda DIC pozwala na szczegółową analizę mierzonych wielkości na całym obszarze badanej próbki. Szeroka analiza pól przemieszczeń i odkształceń za pomocą różnych narzędzi dostępnych w programie Istra 4D, będącym częścią systemu cyfrowej korelacji obrazu 3D Q-450, pozwala na bardzo szczegółowe określenie deformacji próbki i zjawisk zachodzących w czasie obciążania próbki oraz stwarza możliwości różnorodnej wizualizacji wyników badań.

W artykule przedstawiono system cyfrowej korelacji obrazu 3D Q-450 oraz przykładowe zastosowanie tego systemu do rejestracji pól przemieszczeń i odkształceń połączeń śrubowych i spawanych elementów konstrukcji stalowych. Zawarte w artykule wskazówki dotyczące wykonywania pomiarów za pomocą systemu cyfrowej korelacji obrazu mogą być przydatne dla kolejnych użytkowników systemu i przyczynić się do szerszego stosowania metod bezkontaktowych w pomiarach przemieszczeń i odkształceń. 


\section{Literatura}

[1] Kohut P., Kurowski P.: Zastosowanie trójwymiarowych technik wizyjnych do pomiaru i analizy drgań, Diagnostyka, nr 3, 2007, s. 55-63.

[2] Kubit A., Mączka T.: Zastosowanie techniki wizyjnej w pomiarze odkształcenia bezwzględnego warstwy kleju w spoinie, Pomiary Automatyka Robotyka, R. 16, nr 5, 2012, s. 91-97.

[3] Dietrich L., Grzywna P., Kukla D., Wykorzystanie metod optycznych do lokalizacji uszkodzeń zmęczeniowych, Przegląd Spawalnictwa, R. 84, nr 13, 2012, s. 16-18.

[4] Chu T. C., Ranson W. F., Sutton M. A., Peters W. H.: Application of digital-image correlation techniques to experimental mechanics, Experimental Mechanics, no. 25, 1985, pp. 232-244.

[5] Peters W. H., Ranson W. F., Sutton M. A., et al: Applications of digital image correlationmethods to rigid body mechanics, Optical Engineering, no. 22, 1983, pp. 738-742.

[6] Peters W. H., Ranson W. F.: Digital imaging technique in experimental stress analysis, Optical Engineering, no. 21, 1982, pp. 427-431.

[7] Uhl T., Kohut P., Holak K.: Diagnozowanie konstrukcji z zastosowaniem korelacji obrazu, Diagnostyka, nr 3(43), 2007, s. 15-24.

[8] Szymczak T., Kowalewski Z. L., Brodecki A.: Metoda cyfrowej korelacji obrazu w badaniach materiałów i elementów, Dozór Techniczny, z. 4, 2016, s. 22-31.

[9] Hagara M., Huňady R., Lengvarský P., Bocko J.: Numerical Verification of a Fullfield Deformation Analysis of a Specimen Loaded by Combined Loading, American Journal of Mechanical Engineering, vol. 2, no. 7, 2014, pp. 307-311.

[10]Frankovský P., Virgala I., Hudák P., Kostka J.: The use of the digital image correlation in a strain analysis, Int. J. of Applied Mechanics and Engineering, vol. 18, no. 4, 2013, pp. 1283-1292.

[11] Trebuňa F., Huňady R., Bobovský Z., Hagara M.: Results and Experiences from the Application of Digital Image Correlation in Operational Modal Analysis, Acta Polytechnica Hungarica, 2013, vol. 10, no. 5, pp. 159-174.

[12] Instrukcja obsługi systemu Q-450: Q-450 SYSTEM Operation Manual, Dantec Dynamics, 2013.

[13] http://www.dantecdynamics.com/digital-image-correlation (dostęp: 30.09.2016 r.).

[14] Turoń B., Ziaja D., Miller B.: Wykrywanie uszkodzeń węzłów ramy stalowej z wykorzystaniem metody cyfrowej korelacji obrazu, Czasopismo Inżynierii Lądowej, Środowiska i Architektury - Journal of Civil Engineering, Environment And Architecture, JCEEA, tom XXXIV, z. 64 (2/II/17), kwiecień-czerwiec 2017, s. 185-198, DOI: $10.7862 /$ rb.2017.91.

[15] Szymczak T., Grzywna P., Kowalewski Z. L.: Nowoczesne metody określania wytrzymałościowych właściwości materiałów konstrukcyjnych, Transport Samochodowy, z. 1, 2013, s. 79-104.

[16]Lord J. D.: Digital Image Correlation (DIC), Modern Stress and Strain Analysis. A state of the art guide to measurement techniques. BSSM Technical Editors: J. Eaton Evans, J. M. Dulieu-Barton, R. L. Burguete, 2009, s. 14-15.

[17] Kowalewski Z. L., Szymczak T.: Podstawy tensometrii elektrooporowej oraz praktyczne jej zastosowania, Dziewiętnaste Seminarium Nieniszczące Badania Materiałów, Zakopane, 12-15 marca, 1, s. 69-91, 2013.

[18]Błyskal E., Ślęczka L.: Badania doświadczalne rozciąganych kątowników łączonych za pomocą jednej śruby, Czasopismo Inżynierii Lądowej, Środowiska i Architektury 
- Journal of Civil Engineering, Environment And Architecture, JCEEA, tom XXXIII, z. 63 (1/I/16), styczeń-marzec 2016, s. 323-330, DOI:10.7862/rb.2016.38.

[19]D. Kukla, A. Kozłowski: Badania doświadczalne spawanych połączeń kątowników nierównoramiennych z blachą węzłową, Inżynieria i Budownictwo, nr 10, 2016, s. 543-547.

\title{
REGISTRATION AND ANALYSIS OF THE DISPLACEMENTS AND STRAINS FIELDS WITH THE USE OF THE DIGITAL IMAGE CORRELATION SYSTEM 3D
}

\begin{abstract}
S u m m a r y
In recent years, as an alternative to traditional methods of displacements and strains measurements, non-contact methods based on opto-electronic systems have been developed. One of them is the digital image correlation (DIC) system which allows for the registration and analysis of the displacements and strains fields on the surface of the investigated object in three-dimensional space. The paper presents 3D DIC on the example of the Q-450 system from Dantec Dynamics and its application in the study of steel structure elements connections, discusses the principle of its operation and test stages. In addition, the paper describes the applicability of the system, its advantages and limitations. A wide analysis of displacements and strains fields with the use of various tools available in the Q-450 software Istra 4D allows detailed description of the investigated object deformation and the phenomena occurring when the object is loaded. Information presented herein may be useful for future system users and contribute to wider usage of non-contact methods in displacements and strains measurements.
\end{abstract}

Keywords: digital image correlation (DIC), vision methods, non-contact measurement, displacement and strain measurements

Przestano do redakcji: $11.09 .2017 \mathrm{r}$.

Przyjęto do druku: 15.12.2017 r. 